\title{
Material Stretched
}

National Cancer Institute

\section{Source}

National Cancer Institute. Material Stretched. NCI Thesaurus. Code C62835.

Problem associated with an increase or elong ation in a materials' dimension. 